\title{
Berardinelli-Seip congenital lipodystrophy
}

INSERM

\section{Source}

INSERM. (1999). Orphanet: an online rare disease and orphan drug data base.

Berardinelli-Seip congenital lipodystrophy. ORPHA:528

Berardinelli-Seip cong enital lipodystrophy $(\mathrm{BSCL})$ is characterized by the association of lipoatrophy, hypertriglyceridemia, hepatomegaly and acromegaloid features. BSCL belongs to the group of extreme insulin resistance syndromes, which also includes leprechaunism, Rabson-Mendenhall syndrome, acquired generalized lipodystrophy, and types A and B insulin resistance (see these terms). 